\title{
RE-CONNECTING COMMUNITY COLLECTIVE MEMORY WITH THE CHANGE OF LIFE CULTURE AND THE CULTURAL RESISTANCE IN PAKU ALAM VILLAGE, SUMEDANG, WEST JAVA, INDONESIA
}

\author{
Dhini Dewiyanti $^{1^{*}}$, Tri Widianti Natalia $^{2}$, Nova Chandra Aditya ${ }^{3}$ \\ 1,2,3 Lecturer of Architecture Department, Universitas Komputer Indonesia, Bandung, Indonesia
}

\begin{abstract}
Development can be described as two sides of a coin, the first side provides benefits, but on the other side it turns out to have to sacrifice for some people. Jatigede Dam, located in Sumedang Regency, West Java Province, was built in 1998 and its construction resulted in 28 submerged villages. The communities whose areas are submerged must create new villages and switch professions that used to have a livelihood as an agrarian society must switch professions to become aquatic culture communities. This paper discusses experiences in the proposed (re)structuring activities of the Paku Alam Village area in Darmaraja District around the dam. The activity is carried out through the method of recalling the community collective memory, which is brought together with the context of changes in the livelihood culture and ritual culture that is still owned by the village community so that the changing area can be accepted as a "new village" for the community. The data is obtained through searching sites that are considered important by the community, ritual activities that are usually carried out, people's daily lives, and the bad memories of drowned villages, reconciled with the present and future context as part of the region's arrangement. The result is a regional proposal that is expected to meet people's expectations.
\end{abstract}

ARTICLE INFO

\section{Keywords:}

Submerged Village, Collective Memory, Reconnecting, (Re)Structuring, The New Village

\section{Introduction}

A place will be meaningful to someone, especially for those who have lived in a place for generations (Davenport and Anderson, 2005; McAvoy, 2002; Gustafson, 2001). A sense of pride in the place where someone lives will arise when the place we live is part of the history of the origin of culture (Gerson, 2003). Space will be a place when people who use it have a very strong attachment to the place (Qazimi, 2014; Kyle et al., 2004; Hunziker et al., 2007; Massey, 1994). When someone moves to another place, that place still has the power to make someone always have the desire to return (Marcfried, 2000; Gieryn, 2000). But the problem will arise when someone has to move to another place and cannot return to their original place because the place is needed by the government for the national scale development needs. The process of adaptation to the new environment is not an easy problem for anyone and also for the community (Amundsen, 2015). It will take a long time to be able to rebuild the attachment to a new place. Paku Alam Village in Sumedang, West Java, Indonesia, is a village that must be submerged along with 28 other villages due to the construction of the Jatigede dam which will be the second-largest dam in Indonesia. Jatigede Dam is needed to meet the national demand for hydroelectric power. Their original village had to be submerged as a dam requirement, and then be moved to another location, even though it was still in the area around the dam area. Problems become very difficult for the community when villagers have to adapt to the new environment and culture while on the other hand, their memories of the old village still often emerge. During the dry season, the dam lack of water and becomes receding, the old village which is flooded comes to the surface. The old memories that always emerge, must compete with the necessity of society to quickly adapt to the new professions and the new life cultures to survive.

Similar studies have been carried out by Amundsend in 2013 (Massey, 1994) and Clarke in 2018 (Clarke et al., 2018). Amundsend conducted research on the adaptation process of a group of people in two coastal cities in Northern Norway that showed that people are motivated to act based on their emotional connection to the place and serve as a human starting point for adapting. The sense of emotional attachment to the place where they live can cover their disappointment with the disaster they are receiving. Similar results were also shown by Clarke who researched in Clontarf, County Dublin, Ireland. The sense of 
optimism of the people affected by the disaster was shown by making transformative adaptations especially by respecting places that have symbolic meaning for the community.

This paper focuses on the description of the reorganization of new areas by re-connecting people's collective memory and bringing it together with the current context to survive in the future. A community's collective memory is explored through places that are considered important and have strong emotional ties. Memory is also explored through ritual activities, artistic activities, and cultural activities which are still being carried out until now. Data is also carried out by observing the current context and asking about community expectations. By combining people's collective memory with the current context and future hopes, so that the community can have a strong identity in a new place. The power of place will reappear when people already have an emotional attachment to a new place to live. A sense of pride in a place of residence will make people able to compete and survive (Scannel and Gifford, 2010). The results of this finding will contribute to the knowledge of place attachments and the process of community adaptation to new places, and have implications for proposals regarding regional spatial planning.

\section{Literature Review}

A place becomes the basis of how we understand the world and encourage someone to act (Sack, 1992). If we see a place or environment for the second time, we will recognize the place and the parts of the place, such as the object in it, and its background. The most important thing in creating a place is one's personal experience (Tuan, 1974).

A Places are understood as locations (Cresswell, 2004), as social relations and social practices (Kearns and Gesler 1998), as zones of experience and meaning (Wilson, 2003). Therefore, the place will affect one's way of thinking, one's awareness, one's way of life, one's social structure, one's health, and well-being. Both for individuals and society, interaction with places, creation of ideas, concepts, meanings, and symbols of places and landscapes (Williams, 1998). Common values and symbols applied to a landscape will create a shared meaning (Berger and Luckmann, 1967), the natural environment has different roles with different groups, depending on how a group defines itself (Greider and Garkovich, 1994).

The place is not only a physical arrangement and activity but also an arrangement of meaning and emotion. Emotions can increase the ability to remember contextual details about places. Arrangement of meaning and emotion based on a place is called a sense of place which is empirically conceptualized based on various disciplines (Williams et al. 1992). Sense of place consists of an emotional bond with the place, with the values, meanings, and symbols of places, which are actively and continuously being built and reconstructed in the minds of individuals, cultural, historical, and spatial contexts (Williams and Stewart, 1998).

Schroeder (1996) examined the values and emotional ties of the local community with their natural environment through the description of the place. Residents have strong ties of meaning and emotions with their natural environment, they admire the beauty of the natural scenery, wildlife, and geological conditions. They will greatly appreciate the naturalness of culture for a good balance and quality between human facilities and the natural environment (Hull, Robertson, and Kendra, 2001). This is because the naturalness of culture reflects the local identity and way of life of the people. So when a place changes, it will affect one's sense of place (Stedman, 2003).

When a place changes, the community will make creative adaptations. In identity theory, creative adaptation is expressed through place attachments from the principles of identity (Breakwell, 1992). Among them are the specificities (identification of the place used to distinguish oneself from others); Continuity (a place gives a sense of self-continuity because someone has lived in the same place for a long time); Self-esteem (someone feels proud of where they live); Independence (the quality of the residential area facilitates their daily life in various ways).

Place attachment is influenced by several factors, including landscape type (Warzecha and Lime, 2000) experience preference (Peyton 2003), sociodemographic characteristics (Johnson, 1998; Williams et al., 1992), the involvement of recreational activities (Kyle et al., 2003). Place attachment has a relationship with attitude (Warzecha and Lime, 2000) and environmental concern (Vorkinn and Riese, 2001) They found that a better predictor in the development of a dam development area for hydropower was the attachment of residents to areas affected by dam development. But socio-demographic factors can also explain the spatial level of sense of place (Twigger-Ross and Uzzell, 1996).

Therefore, place plays an important role in developing and maintaining self and group identities. Place attachment is important for a person's welfare because it reflects a sense of belonging and purpose that gives meaning to his life (Proshansky et al., 1983). Relph (1976) argues that everyone has a strong relationship with the place they were born or have significant experience.

When a place experiences physical and functional changes, the community will make creative adaptations while maintaining a place identity. This place identity is related to cognition, which includes memories, feelings, attitudes, values, preferences, concepts, and behavioral experiences, which are related to the variety and complexity of physical arrangements. The essence of physical cognition that is determined by the environment is one's 'past environment'. This is determined by its place, space, and characteristics, which provide satisfaction in biological, psychological, social, and cultural terms (Proshansky et al., 1983; Twigger-Ross and Uzzell, 1996).

\section{Research Method}

The location of the observation was carried out in Paku Alam Village in the Darmaraja District, Sumedang (Figure 1). The location of Paku Alam Village is bordered by Cisitu District in the North, the Southwest part is the Jatigede dam and the East is bordered by the Cimanuk River. Because it is close to the location of the dam, then part of the village of Paku Alam became a pool area of Jatigede dam. Located in the Sumedang City area, Paku Alam Village is also close to the Majalengka International Airport area and several 
surrounding city/regency tourist areas. merit or novelties of the paper. Avoid a detailed literature survey or a summary of the results. The introduction should clearly state the purpose of the paper. It should include key references to appropriate work but should not be an historical or literature review.

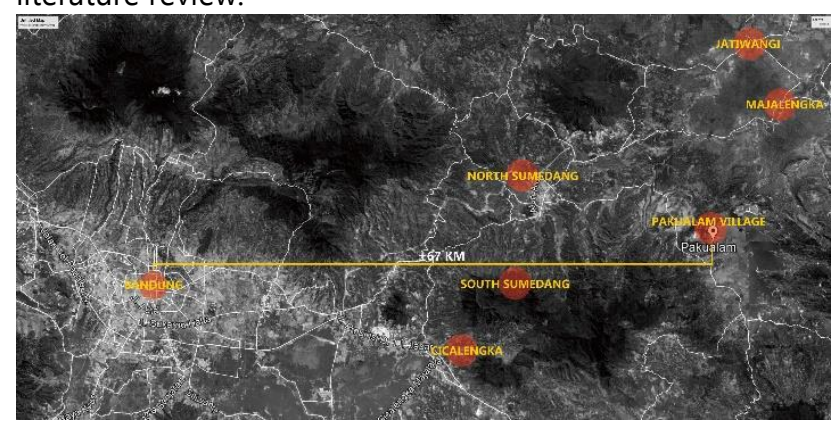

Figure 1. Paku Alam Village and Surrounding Areas Source: Personal Source

\subsection{Research Approach}

This study uses a qualitative research approach with descriptive research categories. This descriptive research is used to explain the rearrangement of new areas by reconnecting people's collective memory and bringing it together with the current context to survive in the future.

\subsection{Data Collection Methods}

Data collection was carried out using unstructured and in-depth interview techniques and non-participant collection (Cresswell, 2014). Unstructured interviews were conducted with informants to explore data on the conditions of the place, actors, and activities of the people of Jatigede Village. Sampling was done by the Snowball Sampling method (Surhone, 2010) The selected sample is to get the latest information in determining locations that are considered important by the community and how they reveal or remember these places, which will further discuss how they are in the future.

The first informant as a source of data was Mr. Archi, who was one of the students from the research campus as well as a native of Sumedang who was active in developing his area. Mr. Archi as an informant who opened the way to recognize the whole area of research widely.

Furthermore, to obtain more complete information on the socio-demographic conditions of the Sumedang research site, Mr. Archi suggested that the researcher interview the 2nd informant, the Secretary of the Sumedang Region, Mr. Herman as the Sumedang Regional Government leaders (Bappeda). From the second informant, data were obtained about the socialdemographic conditions of the population of the Paku Alam Village in the Darmaraja District, Sumedang.

To obtain more accurate data about the condition of the place, actor, and community activities, Mr. Herman suggests researchers interviewed informants 3rd, Mr. Yuyut. Mr. Yuyut is a caretaker or community figure who is considered to have a strong influence in Pakualam Village, Darmaraja District, Sumedang. From this 3rd informant, the researcher immediately made a non-participant observation. The researcher is physically present in Paku Alam Village, but only observes or observes and records systematically the information he gets. This observation is carried out in a long period so that all the data needed is collected in full. Non-participant observation must be made on three components, namely a place, actor, and activity. Observation of the place is carried out to find out which important locations are still present and which have been submerged.

To observe the ritual activities that are still carried out by the surrounding community after the existence of the Jatigede dam, the 3rd Informant suggested researchers interview the 4 th informant who is a community religious figure and cultural expert, Mr. Bayu.

The Snowball technique is continued until it is considered that the data has been fulfilled in full [15]. Up to the 5th informant namely, Mr. Rahmat and the 6th informant is a group of community representatives around the Jatidege dam. From the 5th and 6th informants, data were obtained about locations that were considered important by the community and how they described or remembered the place. Then we also asked about their wishes in the future. The physical objects observed were: the coastal dam, the locations that were considered important by the community, the current location of the residents' work, and the settlements after being relocated. Concerning these locations, the community will measure and observe the use of their space.

\subsection{Data Analysis}

Text data obtained from interviews with participants were analyzed using Content Analysis. Words that come out based on the description described by the participants are identified to get keywords. Then, grouping / categorizing similar keywords, by selecting the words that appear most often, are grouped and reduced and arranged according to the themes that emerge.

The results of the grouping give rise to interpretations in the form of 1 ) important locations both those that still exist or have already sunk; 2) location of expectations; 3) rituals that are still performed; 4) activities expected by villagers. Besides, the results of this grouping can also be used to calculate the frequency category of keywords. Using Distribution Analysis can present a diagram of sociodemographic conditions (livelihoods before and after the Jatigede dam was built) and a diagram of community activities that can be used as hope to develop as an optimism. The results of these interpretations led to proposals to initiate ideas for spatial change that sought to reconcile the collective memory of the people with ideas of future desires.

\section{Results and Discussions}

\subsection{Changes in Livelihood Activities as a Challenge}

The direct impact of the construction of the Jatigede dam is the change in people's livelihoods, especially those related to the submergence of their villages. Figure $2 \mathrm{a}$ shows that before the construction of the dam, $78 \%$ of the community were farmers. Figure $2 b$ shows that after the construction of the Jatigede dam, the profession as a farmer declined by $23 \%$, and showed an increase in unemployment of $49 \%$. There was also an increase in the odd jobs sector, which had only increased by $7 \%$ to $10 \%$. This figure shows that the people affected by the dam construction need to have a strategy to be able to compete and survive. 
Before the Dam Was Built

Livelihood Chart Before the Construction of the Dam

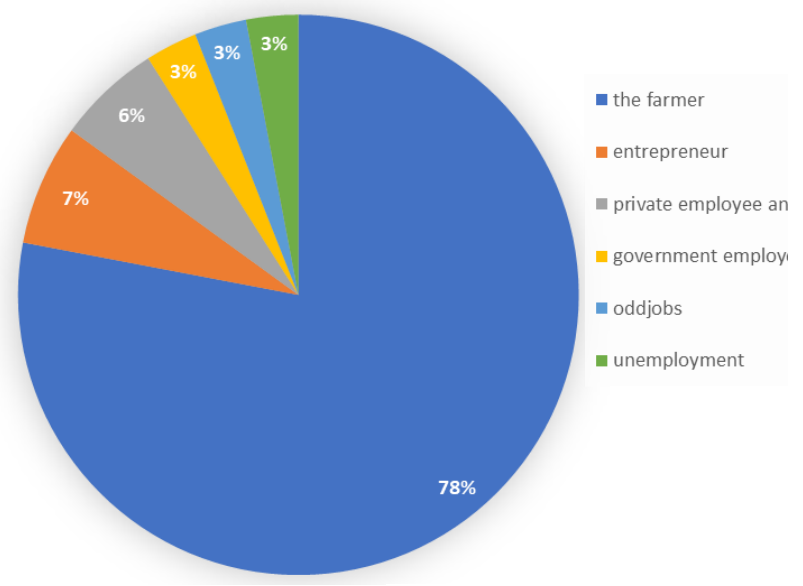

After the Dam Has Been Completed

Livelihood Chart After the Construction of the Dam

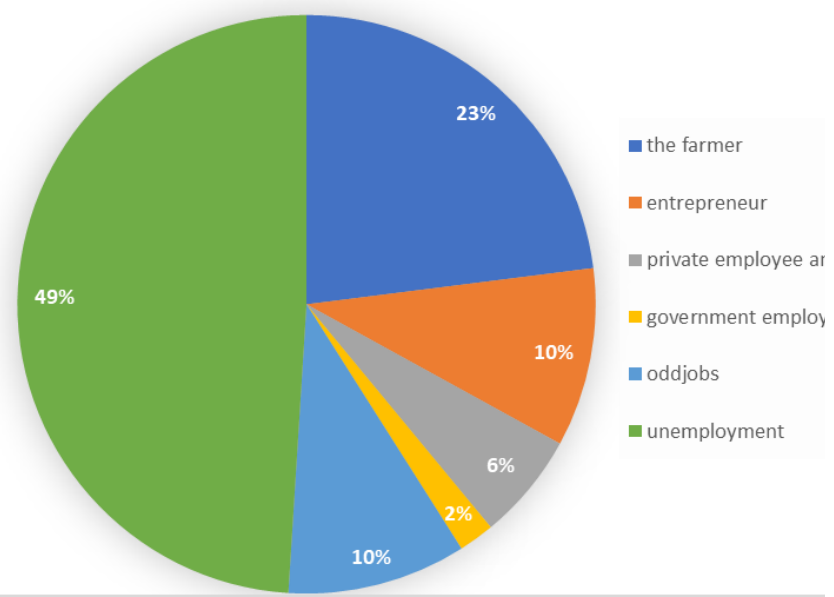

Figure 2. Community Livelihoods Before and After the Jatigede Dam Has Been Completed

Source: Personal Source

\subsection{The Meaningful Location as a Bond of Emotion to The Place}

Some of the locations that are considered important and meaningful by the community are historical sites that are generally ancestral tombs and locations deemed to have sacred values. Institute for the Management of Archaeological History and Tradition Values (BPKSNT) of Culture and Tourism Office (Disparbud) of West Java province records a total of 30 historical sites that are the land of ancestral tombs and 3 spring sites that will sink. The sites are mostly ancestral relics that come from prehistoric times that are continuously enabled by ancestors in historical times. Most sites show the Megalithic traditions re-used during the kingdom of Tembong Agung or Sumedang Larang. Puncak Damar site is located in Cisema Village, Paku Alam Darmaraja subdistrict. This site is a cemetery complex, in which there are three sacred tombs. The sacred tomb of the Puncak Damar site is the grave of Buyut Maja, the tomb of the Embah Entol (Tatang Jalak) and the tomb of Suta Derepa. The tomb is located on the plateau of a ridge that is still considered as an important place and is also directed as a religious tourism destination.

Figure 3 shows there are 25 sites of 30 sites that sunk together with villages that are drowned because of dam needs, there are: Leuwiloa site, Nangewer site, Tembongagung site, Pasir Limus site, Muhara site, Marongpong site, Nangkod site, Jambe site, Lameta site, Betok site located in Leuwihideung Village, Darmaraja subdistrict. The site of Tanjungsari and Munjul site located in Sukamenak Village. Keramat Eretan site located in Cisurat village, Wado subdistrict. Cipawenang site and Cigangsa site, located in the village of Pawenang, Wado subdistrict. Gagak Sangkur site, Tulang Gintung site, Keramat Gunung Penuh site, Keramat Buah Ngariung site located in Padajaya Village, Wado subdistrict. Curug Mas site in Sukakersa Village, Jatigede Sub-district. Cadasngampar site in Sukakersa Village, Jatigede Sub-district. This site is located in Jemah Village, Jatigede Sub-district. Keramat Aji Putih site, the tomb of Queen Ratna Inten Nawangwulan, Tomb of Parbu Aji Putih and the tomb of Resi Agung which is an important figure of the Sunda kingdom and Astana Gede
Cipeueut site located Cipaku village, Darmaraja subdistrict. To mark the existence of the site, the community marks the area of the site by using balloons tied to concrete as markers when they make a pilgrimage by boat (Figure 4). The site is not relocated considering that its existence is unlikely to be replaced by other places. Some sites have different names given by the public with respect to different village origins, although it refers to the use of respect for the same figure.

There are 15 sites relocated from the area of Jatigede Dam, two sites are moved to the Paku Alam Village area: there are Ciseuma site and Astana Leutik site. The site is deemed transferable by moving parts of the site to another place deemed equal to the old place. These sites form a historical concept called Kabuyutan Cipaku, Jatigede Kapunduhan and so on that is the pride of society because it is part of the history of the Sunda Kingdom (Figure 5). Take pride in the origins of these ancestors who keep the community persisted to settle on the region and try to adapt the new space order.

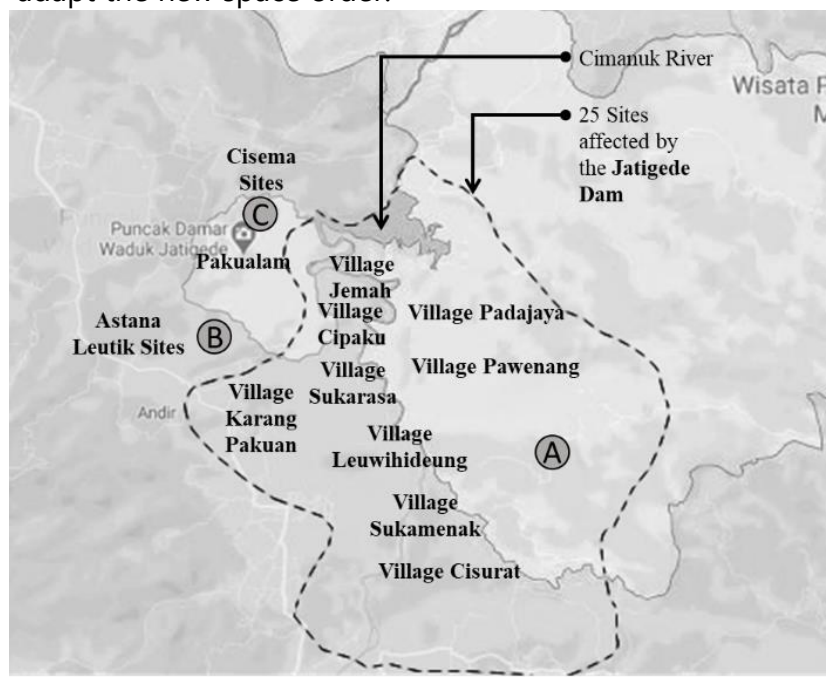

Figure 3. Important Sites in the Area and Around Desa Paku Alam Source: Personal Source 


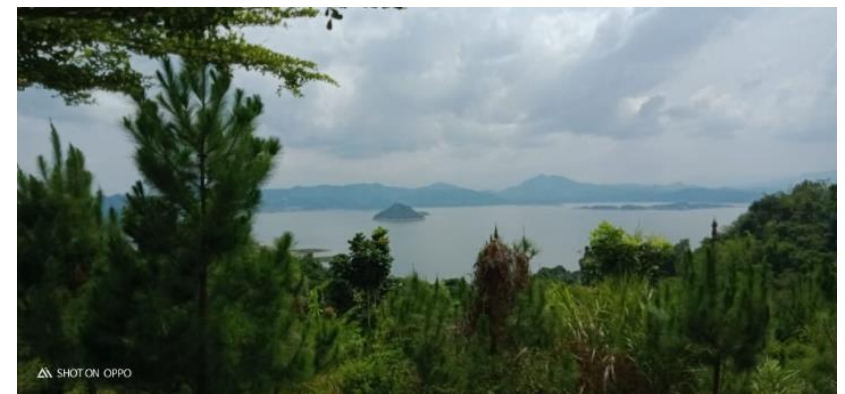

Figure 4. Important Sites in the Area and Around Desa Paku Alam Source: Personal Source

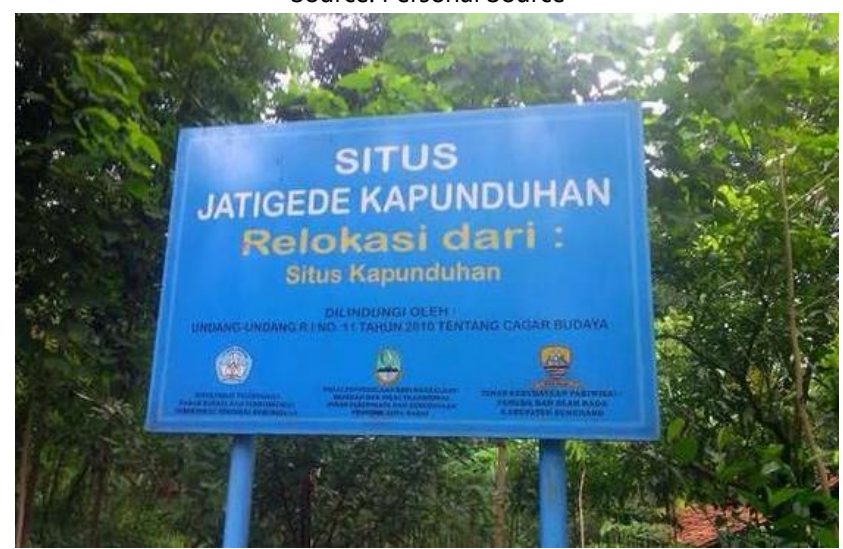

Figure 5. Important Sites in the Area and Around Desa Paku Alam Source: https://jabar.pojoksatu.id/priangan/2015/09/17/baru-satudari-15-situs-di-waduk-jatigede-yang-berhasil-direlokasil

\subsection{Ritual and Arts as A Tradition to Be Preserved}

People are still strong in holding firmly tali paranti (ancestral heritage customs) until now. The customs there are still done by the Jatigede community ranging from the life cycle ceremony (marriage, pregnant, birth, circumcision, and death), the planting cycle ceremony such as the Ngarot ceremony, or Wuku Taun. Ceremonies are related time calendar such as Kaliwonan, Muharaman, Muludan, Rajaban. Some ceremonies are considered to reject calamities such as Ngaruat Anak Tunggal, Upacara Owar, Nyuci Pusaka, Upacara Numbal Bumi, Upacara Nurunan, Rayagung, Ziarah, Buku Taun ceremony, and others.

Besides, there are also traditional arts that still done such as Terebang Gede, Cikuprak, Seni Tayub, Koromong, Beluk, Seni Ajeng, and Tarawangsa. This art remains preserved by the community along with the pride of the society on the remaining ancient manuscripts and still the keeping of the expression of Sundanese proverbs that until now hereditary still taught by parents to their children.

\subsection{Build a New Village as an Adaptation Process}

There are new locations that are formed in a natural, as well as areas deliberately made by the community after the Jatigede Dam, which is directed as a location for tourist destinations such as Puncak Damar, Buricak Burinong Village, Buhun Cipaku Village, Camping Area, several site areas as a pilgrimage zone, and Jatigede Dam as a tourist destination (Figure 6). Puncak Damar in addition to being a place of sacred sites, because it is in a high and strategic position, has a beautiful view. Buricak Burinong Village is a new village due to the displacement of residents affected by the dam area. The village is deliberately decorated with a colorfully painted roof to look attractive. The village area also features a photo location spot for travelers who want to take selfies. Buhun Village is a village that is also formed following ancestral rules that show Sundanese culture. These locations continue to be developed by the community, assisted by some figures, cultural and government observers to attract local and foreign tourists. An effort to make the village as a tourist destination continue to be done along with changes in the livelihood of people who previously were farmers had to switch functions in other professions to survive.

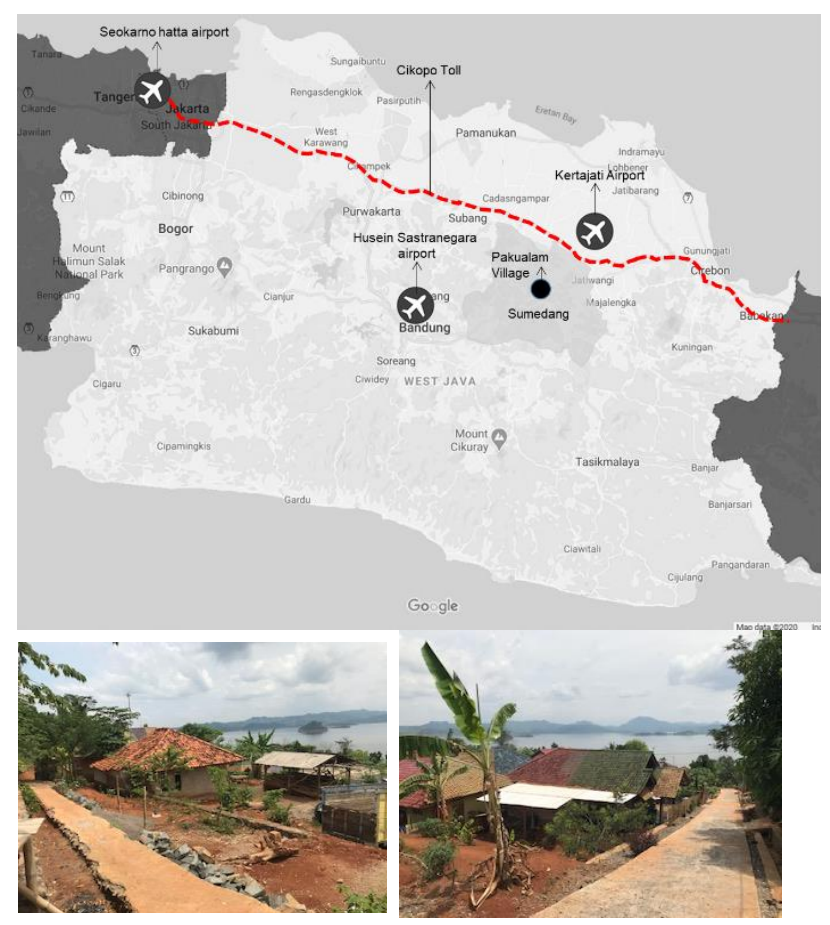

Figure 6. Location of the Developments Source: Personal Source

\subsection{A View of the Future, Hopes and Dreams for Growth as an Optimism for The Progress of The Village}

Most people have a passion and optimism to contribute to the village, especially to survive and adapt to new environments. Diagram in Figure 7 shows $30 \%$ of people hoping to be able to sell in food stalls around the dam, 15\% hope to make a home industry in the processing of fish in the dam, 10\% make souvenir shop, $7 \%$ make a support services dam tourism. All of these communities are optimistic to support tourism activities due to the Jatigede dam. But there are still about $20 \%$ of people who do not know what to do, and $5 \%$ just hoping to the mercy of the government. This society that still must be given socialization and confidence. 
Activities that Community Wants to Do

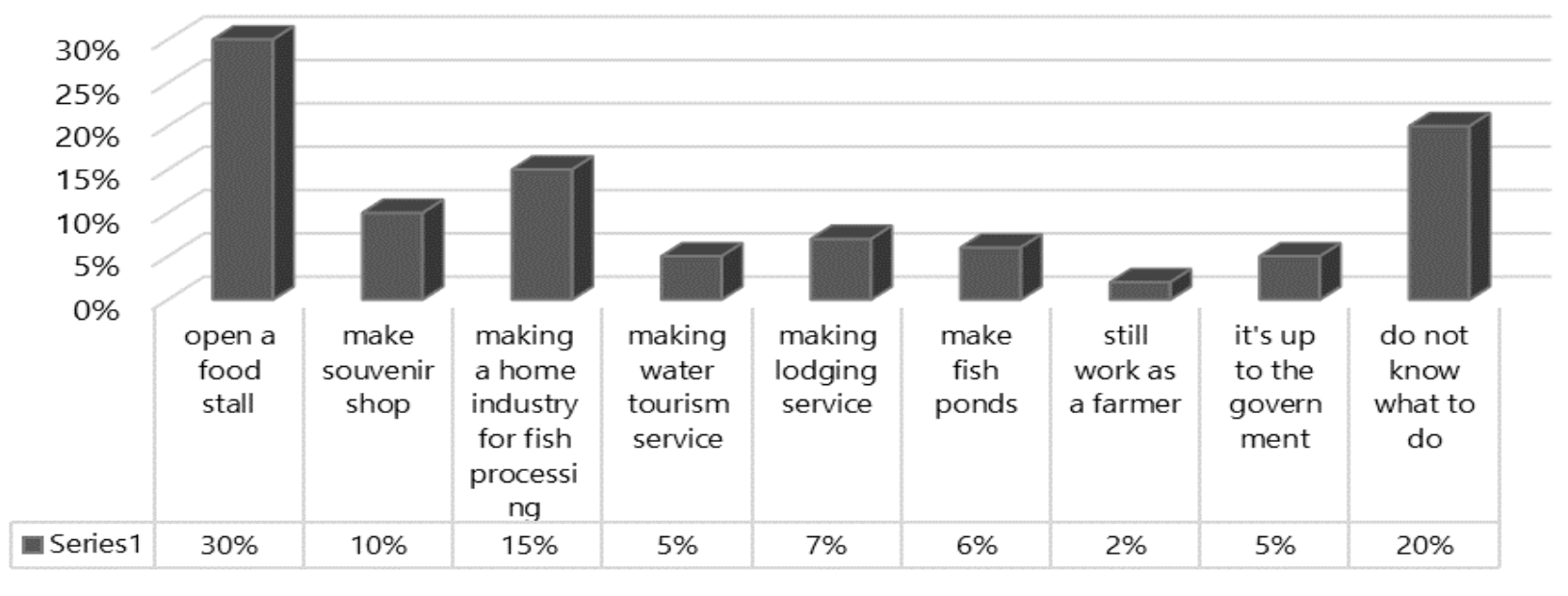

Figure 7. Diagram of Activity

Source: Personal Source

\subsection{Discussion}

\section{Pride Attitude and Place Attachment as The First Step of Adaptation Attempts}

We agree with Amundsend's opinion that states that the emotional ties of a community are the first step to the adaptation process. Place attachments on social dimensions related to family and offspring that occur over a long period can make a community have an attachment to the place. For the Paku Alam Village Community, this is reinforced by their pride as part of the history of the Sunda Kingdom. The feeling of pride and the emotional ties that exist make people stay afloat and not move to other places. Although it must be relocated to a new place around the dam, the closeness to the place gives the community still want to adapt and feel close to the old place. This is the basic capital as the initial step of the people's desire to adapt to the new environment.

\section{Sense of Pride in Parts of Sundanese History and Place Attachment as the First Step to Adaptation}

Collective memory can also be used to re-identify a group that has experienced a traumatic event. Collective memory builds community cohesion ties and can be a cultural movement variable. In the liminal phase experienced by Paku Alam Village residents who experience changes in individual or community identity, when the community experiences an event of cultural disorientation, collective memory is energy to reminisce so that it cannot be separated from the cultural thread. Bad events can be remembered or forgotten to shape thought, or form a social identity for a person or society. The purpose to remember the past is to make lessons so that an event does not happen again. The collective memory of the people in an area cannot be ignored because it will cause the indigenous population of the region to become extinct along with their social and cultural potential to be replaced by a new population. Collective memory plays an important role in the sustainability of conservation of an area. Collective memory emphasizes the social and cultural conditions of an environment, thereby causing a link between a place and a population. Collective memory is an effective link between generations to see past events and design the future of a place or region. Clarke produced the finding that the attitude to accept the impact becomes something that must be addressed as motivation to move forward. An optimistic attitude to life seems to be somewhat lacking in the affected Paku Alam Village community. With the existence of people who do not know what to do or accept whatever is given by the government, the government must approach and motivate so that people want to struggle to progress and rise from adversity. The collective memory of the community about meaningful places, rituals, and arts that are still being carried out, makes many activities must be planned so that the community can rise from the sense of loss of place. Activities and roles of the community that can be created, to form a "new identity", can be seen in Table 1.

Self-identification with places, historical activities, and cultural participation are three categories of steps taken to recall people's connections to the past to be presented in the context of the present life. Self-identification that they must now realize that the landscape of their settlements has a dam as a part that must be accepted. The identity that changes from a farming community to a water culture community must begin to be trained. Awareness of place identity for places is done through a combination of economic activities: training the culture of tourism communities by utilizing reservoirs for water tourism, hills for camping tourism, and homes as a place of livelihood that utilizes and produces the results of dams. Houses, dams (water), and hills must become an awareness of the place as part of people's lives. The identity of history is carried out through pilgrimage activities and speaking activities or forming a storytelling community in the form of plays, puppets, and so on as an effort to introduce history. The formation of community identity through cultural participation is done by organizing cultural week which is an annual agenda of the community. The third activity is the formation of awareness of identity that connects memories to be carried out in the current context, is expected to form a new place attachment for future generations. 
Table 1. Existing Activities and Future Plans

\begin{tabular}{|c|c|c|c|}
\hline $\begin{array}{l}\text { Existing Tourism } \\
\text { Activities }\end{array}$ & Potential Tourism Activities & Actor & Role \\
\hline $\begin{array}{l}\text { Travel around the dam } \\
\text { lake by boat }\end{array}$ & $\begin{array}{l}\text { Conduct other water tourism } \\
\text { development activities (water } \\
\text { sports and leisure facilities) }\end{array}$ & The community around the dam & $\begin{array}{l}\text { The role of the community is to provide } \\
\text { water tourism support services such as: } \\
\text { the attractions, the equipment rental, } \\
\text { the safety, and so on }\end{array}$ \\
\hline $\begin{array}{l}\text { Religious tours visiting } \\
\text { ancestral sites or graves }\end{array}$ & $\begin{array}{l}\text { Make improvements to site } \\
\text { facilities with supporting facilities } \\
\text { such as toilets and shops selling } \\
\text { pilgrimage facilities }\end{array}$ & Community leaders & $\begin{array}{l}\text { Organizing religious tours based on } \\
\text { time that is aligned with cultural } \\
\text { activities }\end{array}$ \\
\hline $\begin{array}{l}\text { Held a celebration of } \\
\text { ritual culture, art, religious } \\
\text { events, and cultural } \\
\text { traditions of the village. } \\
\text { The event of book review } \\
\text { of the history of the Paku } \\
\text { Alam Village }\end{array}$ & $\begin{array}{l}\text { Holding Sundanese dance and } \\
\text { art workshops, plantation } \\
\text { workshops, fisheries cultivation } \\
\text { workshops }\end{array}$ & $\begin{array}{l}\text { Karang Taruna, a community of } \\
\text { cultural activists and historians }\end{array}$ & $\begin{array}{l}\text { Hold the workshops that are held daily, } \\
\text { monthly, yearly. Holding village cultural } \\
\text { performances based on rituals that are } \\
\text { usually performed by the community. } \\
\text { Creating annual folk festivals that can } \\
\text { become village icons, and making the } \\
\text { city of Sumedang famous }\end{array}$ \\
\hline $\begin{array}{l}\text { House Painting Activities } \\
\text { in Buricak Burinong } \\
\text { Village }\end{array}$ & $\begin{array}{l}\text { The development of welfie } \\
\text { tourism in residential areas and } \\
\text { the making of guest houses } \\
\text { phase } 2\end{array}$ & The community around the dam & $\begin{array}{l}\text { The community paints their houses as } \\
\text { attractive as possible using the funds } \\
\text { that will be sought by the village } \\
\text { manager }\end{array}$ \\
\hline $\begin{array}{l}\text { Puncak Damar Jatigede } \\
\text { Tourism }\end{array}$ & $\begin{array}{l}\text { Development of forest trail } \\
\text { connected with Puncak Damar } \\
\text { area (stage 2) }\end{array}$ & The community and PERHUTANI & $\begin{array}{l}\text { Cooperating with Perhutani in } \\
\text { managing the forest trail connected to } \\
\text { the Jatigede dam }\end{array}$ \\
\hline Jatigede Camping Ground & $\begin{array}{l}\text { Development of camping } \\
\text { ground areas connected to } \\
\text { Puncak Damar forest trail area } \\
\text { (stage 2) }\end{array}$ & The community and PERHUTANI & $\begin{array}{l}\text { Cooperating with Perhutani in } \\
\text { developing the camping ground which } \\
\text { is connected to the Jatigede dam and } \\
\text { the forest trail }\end{array}$ \\
\hline $\begin{array}{l}\text { Making a dam side } \\
\text { restaurant with traditional } \\
\text { food from Paku Alam area }\end{array}$ & $\begin{array}{l}\text { The development of regional } \\
\text { specialties whose types can be } \\
\text { compromised jointly by the } \\
\text { community so that no similar } \\
\text { competition occurs }\end{array}$ & $\begin{array}{l}\text { The farmer women groups } \\
(\mathrm{KWT}) \text {, the village activist } \\
\text { woman, the youth clubs, the } \\
\text { communities around the } \\
\text { Jatigede dam }\end{array}$ & $\begin{array}{l}\text { Providers and managers of restaurants, } \\
\text { major raw material providers, providers } \\
\text { of supporting materials }\end{array}$ \\
\hline $\begin{array}{l}\text { Making a home industry } \\
\text { Processing food derived } \\
\text { from fish that are } \\
\text { cultivated in dams }\end{array}$ & $\begin{array}{l}\text { Activities for developing other } \\
\text { processed fish industries such as: } \\
\text { fish spines, fish skins, and other } \\
\text { non-food products. } \\
\text { Development of folk handicraft } \\
\text { products }\end{array}$ & $\begin{array}{l}\text { The farmer women groups } \\
(\mathrm{KWT}) \text {, the village activist } \\
\text { woman, the youth clubs, the } \\
\text { communities around the } \\
\text { Jatigede dam }\end{array}$ & $\begin{array}{l}\text { Manufacturing and marketing of } \\
\text { processed products }\end{array}$ \\
\hline
\end{tabular}

\section{Collective Memory Replacement}

What the Paku Alam villagers are doing is actually an effort to replace their collective memory into a new place. They also moved some of the relocatable sites to new locations and tried to build the same impression of the old place. The types of houses and villages are also made as similar as possible to their original villages. Lots of assistance from various parties to paint their village with colors so that the village looks more festive. The village coloring is expected by the community to attract tourists to visit their village which will be directed as a tourist village. However, it should be noted that several villages in Indonesia such as in Kampung Jodipan, Malang (Figure 8); Kampung Kalisari, Semarang (Figure 9); Kampung Teluk Bitung, Bandar Lampung (Figure 10); Kampung Teluk Seribu, Balikpapan (Figure 11); Kali Code, Yogyakarta
(Figure 12); Kampung Bulak Kenjeran, Surabaya (Figure 13) and many other villages in Indonesia, have also appeared as colorful villages beforehand. Apart from the first, these villages were also better managed and organized. There is a need for another approach apart from village arrangement which is merely painting houses so that Paku Alam village has more unique characteristics that are different from other villages in Indonesia. If there is no further action to relocate in a better order, then the act of painting the village will be useless. Re-creating the collective memory of villagers as a form of appreciation for the past also needs to be accompanied by strengthening the community with historical values of their ancestors. 


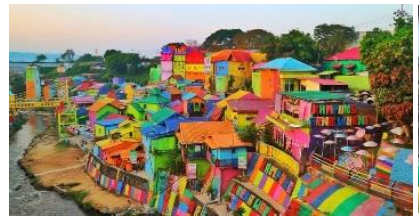

Figure 8. Kampung Jodipan, Malang

Source:https://travel.okezone. com/read/2018/12/08/406

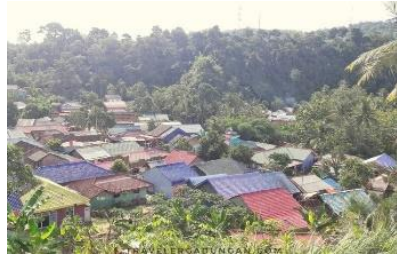

Figure 10. Kampung Teluk Bitung, Bandar Lampung

Source: https://phinemo.com/ kampung-warna-warni

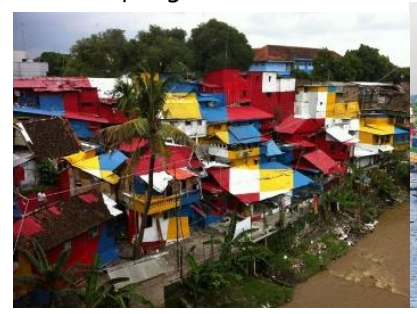

Figure 12. Kampung Kal Code, Yogyakarta

Source: https://phinemo.com/

kampung-warna-warni

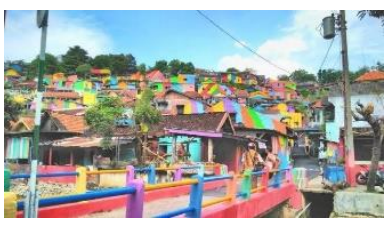

Figure 9. Kampung Kalisari, Semarang

Source:https://jatimtimes.com/ baca/183881/20181205

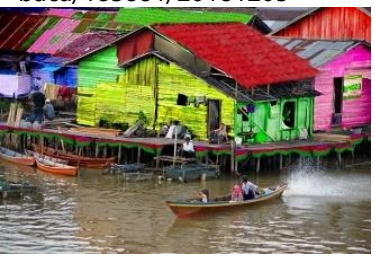

Figure 11. Kampung Teluk Seribu, Balikpapan

Source: https://phinemo.com/ kampung-warna-warni

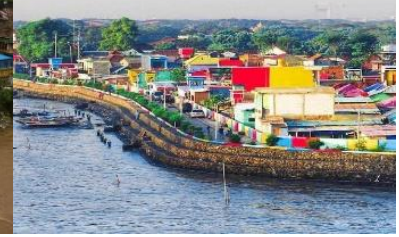

Figure 13. Kampung Bulak Kenjeran, Surabaya

Source:https://jatimtimes.com/ baca/183881/20181205

A sense of pride in the past needs to be accompanied by a deep knowledge of stories, myths, and ancestral pride that can be sold to the outside community. This strength will eventually be able to complement the existence of the important sites and locations, which will be accompanied by the appearance of Sundanese daily culture in the past in the form of art and living culture. The daily lives of people who appear with cultural strengths with all the historical stories and myths, will attract many tourists, especially the foreign tourists.

\section{Conclusion}

The collective memory of the community finds that there are places which considered important and have a meaning that gives a sense of pride in the origins of ancestors. This emotion motivates the community to stay in the region and try to adapt to the present context. Life culture changes give the spirit to compete in the world of tourism, although a small part of society still requires the role of the government to provide direction.

\section{References}

Amundsen, H. (2015). Place Attachment as A Driver of Adaptation in Coastal Communities in Northern Norway. Local Environment Journal, 2O(3), 257-276. DOI: 10.1080/13549839.2013.838751

Berger, P.L. and Luckmann, T. (1967). The Social Construction of Reality: A Treatise in the Sociology of Knowledge. Garden City, NY: Anchor Books

Breakwell, G.M. (1992). Processes of Self-evaluation: Efficacy and Estrangement. In G.M. Breakwell (Ed.). Social Psychology of Identity and the Self Concept (pp. 33-55). London: Surrey

University Press

Clarke, D., Murphy, C., Lorenzoni, I. (2018). Place Attachment, Disruption and Transformative Adaptation. Journal of Environmental Psychology, 55, 81-89

Cresswell, T. (2004). Place: A Short Introduction. Malden, Oxford, Victoria: Blackwell Publishing

Cresswell, J.W. (2014). Research Design: Qualitative, Quantitative and Mixed Method Approaches (4th ed). SAGE Publications

Davenport, M.A. and Anderson, D.H. (2005). Getting from Sense of Place to Place-Based Management: An Interpretive Investigation of Place Meanings and Perceptions of Landscape Change. Journal of Society \& Natural Resources, 18(7), 625641. DOI: 10.1080/ 08941920590959613

Gerson, S. (2003). The Pride of Place: Local Memories \& Political Culture in Nineteenth-Century France. Ithaca \& London: Cornell University Press

Gieryn, T.F. (2000). A Space for Place in Sociology. Annual Review of Sociology, 26(1), 463-96. DOI: 10.1146/annurev.soc.26.1.463

Greider, T. and Garkovich, L. (1994). Landscapes: The social construction of nature and the environment. Rural Sociology, $59,1-24$

Gustafson, P. (2001). Meanings of Places: Everyday Experience and Theoretical Conceptualizations. Journal of Environmental Psychology, 21(1), 5-16

Hull, R.B., Robertson, D.P., Kendra, A. (2001). Public Understandings of Nature: A Case Study of Local Knowledge About "Natural" Forest Conditions. Society Natural Resources, 14(4), 325-340

Hunziker, M., Buchecker, M., Hartig, T. (2007). Space and Place Two Aspects of the Human-landscape Relationship. In Kienast F., Wildi O., Ghosh S. (Eds.) A Changing World. Landscape Series, vol 8. Dordrecht: Springer. DOI: 10.1007/978-1-4020-4436-6_5

Johnson, C.Y. (1998). A Consideration of Collective Memory in African American Attachment to Wildland Recreation Places. Human Ecology Review, 5(1), 5-15

Kearns, R. and Gesler, W. (1998). Introduction. In Kearns, R., Gesler, W. (Eds.) Putting Health into Place: Landscape, Identity and Well-Being (pp. 1-13). Syracuse: Syracuse University Press

Krippendorff, K. (1980). Content Analysis: An Introduction to Its Methodology. Beverly Hills: Sage Publications

Kyle, G., Graefe, A., Manning, R., Bacon, J. (2003). An Examination of the Relationship between Leisure Activity Involvement and Place Attachment among Hikers Along the Appalachian Trail. Journal of Leisure Research, 35(3), 249-273

Kyle, G.T., Mowen, A.J., Tarrant, M. (2004). Linking Place Preferences with Place Meaning: An Examination of The Relationship Between Place Motivation and Place Attachment. Journal of Environmental Psychology, 24(4), 439-454

Fried, M. (2000). Continuities and Discontinuities of Place. Journal of Environmental Psychology, 20(3), 193-205

Massey, D. (1994). Space, Place and Gender. Polity Press

McAvoy, L. (2002). American Indians, Place Meanings and the Old/New West. Journal of Leisure Research, 34(4), 383396. DOI: 10.1080/00222216.2002.11949978

Peyton, M.A. (2003). Influence of Place Attachment and Social Capital on Civic Action: A study at Sherburne National Wildlife Refuge. Plan B, master's thesis, Conservation Biology, University of Minnesota, St. Paul

Proshansky, H., Fabian, A.K., Kaminoff, R. (1983). Place Identity: Physical World Socialization of the Self. Journal of Environmental Psychology, 3(1), 57-83

Relph, E. (2008). Sense of Place and Emerging Social and Environmental Challenges. In Eyles, J., Williams, A. (Eds.) Sense 
of Place, Health and Quality of Life (pp. 31-44). Farnham, Burlington: Ashgate Publishing Company

Sack, R.D. (1992). Place, Modernity, and the Consumer's World: A Relational Framework for Geographic Analysis. Baltimore, MD: Johns Hopkins University Press

Scannel, L. and Gifford, R. (2010). Defining Place Attachment: A Tripartite Organizing Framework. Journal of Environmental Psychology, 30(1), 1-10

Schroeder, H.W. (1996). Ecology of the Heart: Understanding How People Experience Natural Environments. In A.W. Ewert (Ed.). Natural Resource Management: The Human Dimension (pp. 1327). Boulder, CO: Westview Press

Stedman, R.C. (2003). Is It Really Just a Social Construction?: Contribution of the Physical Environment to Sense of Place. Society Natural Resources, 16(8), 671-686

Surhone, L.M., Tennoe, M.T., Henssonow, S.F. (2010). Snowball Sampling. Betascript Publishing

Tuan, Y.F. (1974). Topophilia: A Study of Environmental Perception, Attitudes and Values. New York: Columbia University Press

Twigger-Ross, C.L. and Uzzell, D.L. (1996). Place and Identity Processes. Journal of Environmental Psychology, 16(3), 205-220

Warzecha, C.A. and Lime, D.W. (2000). Place Attachment in Canyonlands National Park: Visitors' Assessment of Setting Attributes on the Colorado and Green Rivers. The Journal of Park and Recreation Administration, 19(1), 59-78

Weber, R.P. (1990). Basic Content Analysis. Newbury Park: Sage Publications

Williams, D.R., Patterson, M.E., Roggenbuck, J.W., Watson, A.E. (1992). Beyond the Commodity Metaphor. Leisure Sciences, 14, 29-46

Williams, D.R. and Stewart, S.I. (1998). Sense of Place: An Elusive Concept that is Finding a Place in Ecosystem Management. Journal of Forestry, 66(5), 18-23

Wilson, K. (2003). Therapeutic Landscapes and First Nations Peoples: An Exploration of Culture, Health and Place. Health \& Place, 9, 83-93

Qazimi, S. (2014). Sense of Place and Place Identity European. Journal of Social Sciences Education and Research, 1(1), 306-310 